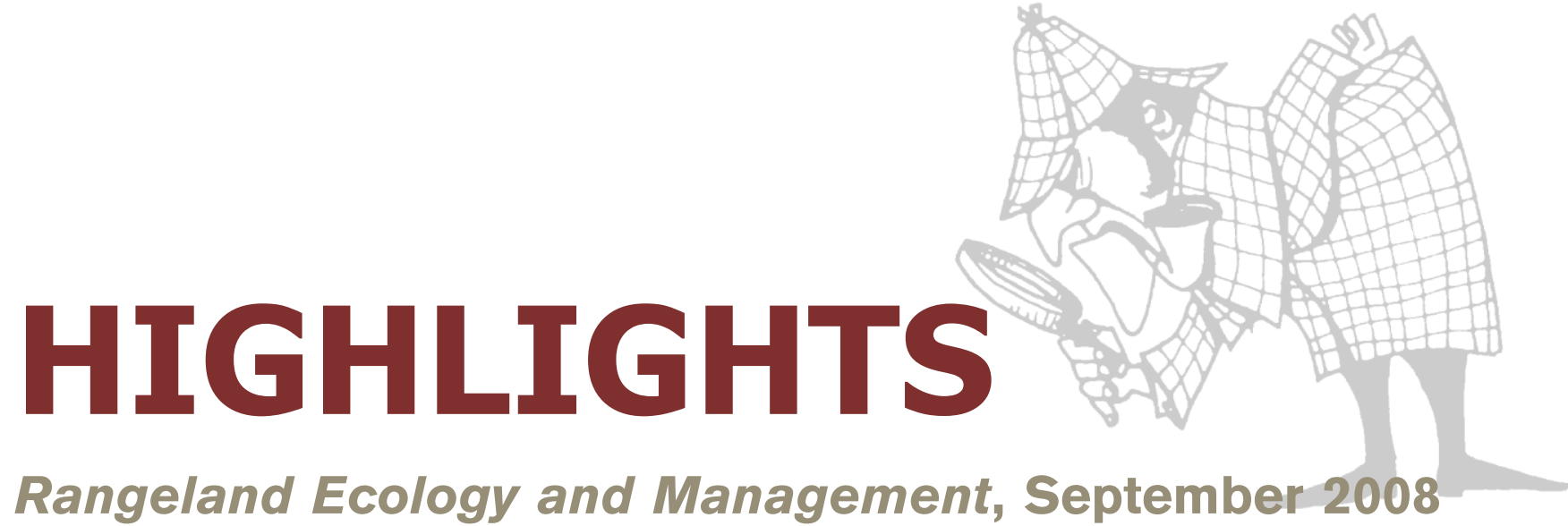

\section{Carbon Fluxes on North American Rangelands}

Tony Svejcar, Raymond Angell, Jim Bradford, William Dugas, William Emmerich, Albert B. Frank, Tagir Gilmanov, Marshall Haferkamp, Douglas A. Johnson, Herman Mayeux, Pat Mielnick, Jack Morgan, Nicanor Z. Saliendra, Gerald E. Schuman, Phillip L. Sims, and Kereith Snyder

Net ecosystem exchange of carbon (NEE) was studied over a 6-yr period with the Bowen ratio-energy balance system on eight North American rangeland sites for continuous measurements of energy, water vapor, and $\mathrm{CO}_{2}$ fluxes. Both sagebrush steppe sites were sinks, and three of four Great Plains grasslands were sinks, but the two Southwest hotdesert sites were sources of carbon (C) on an annual basis. Most rangelands were characterized by short periods of high $\mathrm{C}$ uptake $(2 \mathrm{mo}$ to $3 \mathrm{mo})$ and long periods of $\mathrm{C}$ balance or small respiratory losses of $\mathrm{C}$. Weather patterns strongly influenced NEE with drought, causing even the most productive sites to become sources of $\mathrm{C}$ on an annual basis. These results show that native rangelands are a potentially important terrestrial sink for atmospheric $\mathrm{CO}_{2}$.

\section{Effects of Nitrogen Availability and Cheatgrass Competition on the Establishment of Vavilov Siberian Wheatgrass}

Monica B. Mazzola, Kimberly G. Allcock, Jeanne C. Chambers, Robert R. Blank, Eugene W. Schupp, Paul S. Doescher, and Robert S. Nowak

The objective of this study was to evaluate the potential of 'Vavilov' Siberian wheatgrass (Agropyron fragile) to establish on cheatgrass-dominated sites. Establishment of Vavilov was evaluated in response to different levels of soil nitrogen availability by adding sucrose to the soil to promote $\mathrm{N}$ immobilization and to competition by seeding different levels of cheatgrass. In the first year after seeding, sucrose reduced cheatgrass density by $35 \%$ and decreased both cheatgrass biomass $\cdot \mathrm{m}^{-2}$ and seed production $\cdot \mathrm{m}^{-2}$ by $67 \%$. These effects were temporary, and by the second year after seeding there was a 7-fold increase in cheatgrass density. Short-term reductions in $\mathrm{N}$ or cheatgrass seed supply did not have long-term effects on cheatgrass and did not increase Vavilov establishment.

\section{Effects of Slash on Herbaceous Communities in Pinyon-Juniper Woodlands of Northern Arizona}

Michael T. Stoddard, David W. Huffman, Thom M. Alcoze, and Peter Z. Fule

Understory conditions of many pinyon-juniper woodlands in the western United States are showing symptoms of degradation likely resulting from overuse and tree competition. We established an experiment to examine the effects of slash additions on graminoid establishment, soil stability, and soil biota. Our results suggest that scattered slash material can promote the establishment of grasses, improve soil conditions, and potentially enhance important soil-plant interactions. Slash application holds promise for contributing to the long-term resilience of native plant communities in southwestern pinyon-juniper woodlands.

\section{Interannual Herbaceous Biomass Response to Increasing Honey Mesquite Cover on Two Soils}

W. Richard Teague, R. Jim Ansley, William E. Pinchak, Steven L. Dowhower, Shannon A. Gerrard, and J. Alan Waggoner

In the southwestern United States, honey mesquite (Prosopis glandulosa) encroachment forms closed-canopy woodlands, which significantly reduce herbaceous productivity; thus threatening the sustainability of livestock production and 
altering wildlife habitat. Herbaceous biomass responses to increased honey mesquite cover were quantified on two soils from 1995 to 2001 in north-central Texas. Herbaceous biomass decreased linearly with increasing mesquite cover $\left(29 \mathrm{~kg} \cdot \mathrm{ha}^{-1} \cdot \mathrm{cm}^{-1}\right.$ precipitation January-September at $100 \%$ mesquite cover). Cool-season herbs were least affected. Increasing mesquite cover intensifies drought effects by increasing annual herbaceous biomass variability and there is little advantage to having mesquite present for forage production goals.

\section{Long-Term Response Patterns of Tallgrass Prairie to Frequent Summer Burning}

\section{E. Gene Towne and Ken E. Kemp}

How tallgrass prairie responds to fire in the growing season is based primarily upon studies that are spatially or temporally limited. Species cover and richness were evaluated over a 14-yr period from ungrazed prairie that was burned biennially in the growing season (July-August). The primary responses from summer burning were an increased number of annual forbs and the proliferation of aster species, with no reduction in any warm-season grasses. Increases in floristic richness and diversity from summer fire compared with spring fire suggest that burning ungrazed prairie in the summer is a potentially useful tool to increase community heterogeneity.

\section{Microchannels Affect Runoff and Sediment Yield From a Shortgrass Prairie}

Selina A. Koler, G. W. Frasier, M. J. Trlica, and J. D. Reeder

Runoff from rangelands is a complex process that involves interactions among landform, soils, and vegetation. Rainfall simulations quantified the effects of microchannels and soil removal on runoff and sediment loss from good and fair range condition areas on a shortgrass prairie in northern Colorado. Microchannels increased total runoff but reduced the sediment yield per unit of runoff from fair range condition areas dominated by buffalo grass compared to good condition areas dominated by blue grama and western wheatgrass. The study gives insight into how rangeland surface microtopography, vegetation composition, and growth form affect runoff and sediment transport processes.

\section{Combined Impacts of Native Grass Competition and Introduced Weevil Herbivory on Canada Thistle (Cirsium arvense)}

Ángel Ferrero-Serrano, Timothy R. Collier, Ann L. Hild, Brian A. Mealor, and Thomas Smith

Biological control and native grass competition should be complementary forces in reducing the return of invading weeds, although integration of the two is seldom studied. We investigated combined impacts of a stem-mining weevil (Ceutorhynchus litura), used for Canada thistle biological control, alone and in combination with either needle and thread grass (Hesperostipa comata) or alkalai sacaton (Sporobolus airoides) in greenhouse competitive plantings. Benefits of weevil presence as an augmentation of grass competition depend on appropriate timing and weevils provided the most benefit to the cool season grass competitor. Restoration of former Canada thistle sites with native grasses may be facilitated with insect biocontrol.

\section{Temporal Variation in Diet and Nutrition of Preincubating Greater Sage-Grouse}

\section{Michael A. Gregg, Jenny K. Barnett, and John A. Crawford}

Understanding the functional response of greater sagegrouse (Centrocercus urophasianus) to changes in resource availability is critical for effective sage-grouse habitat management. We investigated temporal variation in diet composition and nutrient content (crude protein, calcium, and phosphorus) of foods consumed by preincubating female sage-grouse relative to food supply. Our results indicate that increased forb abundance in areas used by female sage-grouse prior to nesting would increase their forb consumption and nutritional status for reproduction. We recommend that managers should emphasize delineation of habitats used by preincubating sage-grouse and evaluate the need for enhancing forb abundance and diversity.

\section{Does Doramectin Use on Cattle Indirectly Affect the Endangered Burrowing Owl?}

Kevin D. Floate, Patrice Bouchard, Geoff Holroyd, Ray Poulin, and Troy I. Wellicome

Residues in dung of cattle treated with parasiticides can kill dung-breeding insects to affect the availability of food for insectivorous birds. We tested the potential for one such product (doramectin) to indirectly affect burrowing owls, an "endangered" species in Canada. Dung from cattle treated up to 16 wk previously with a recommended, topical dose of doramectin produced fewer numbers of at least some insect species. However, dietary analyses showed dungbreeding beetles to comprise only $0.1 \%$ of the biomass consumed by burrowing owls. We conclude that recommended use of doramectin on pastures is unlikely to harm burrowing owls.

\section{Jaguar and Puma Predation on Cattle Calves} in Northeastern Sonora, Mexico

Octavio C. Rosas-Rosas, Louis C. Bender, and Raul Valdez

Predation by endangered jaguars and pumas is a source of conflict with cattle ranching in Sonora, Mexico. We 
documented jaguar and puma predation on cattle from 1999 through 2004. Jaguars and pumas killed only calves $<12$ mo old, and annual predation rates were low (1.8\%); calf survival was high (89-98\%); and overall impacts of predation were minor compared with other causes of mortality. Because predation was spatially and temporally patchy, most persistent conflicts could be ameliorated by targeting problem cats and adopting modified husbandry practices designed to keep cattle away from riparian corridors during dry seasons.

\section{Common Broomweed Growth Characteristics in Cleared and Woody Landscapes}

Roy L. Stanford, R. James Ansley, and Dean Ransom, Jr

During an extreme outbreak of broomweed (Amphiachyris dracunculoides) in northern Texas in 2007, we observed apparent differences in broomweed plant growth in mesquite (Prosopis glandulosa) woodland areas versus areas that had recently been cleared of mesquite. Individual plant mass, canopy diameter, and basal stem diameter were much greater in the cleared treatment than in the mesquite woodland, while plant height was greater in the woodland than in the cleared treatment. Total perennial grass production was greater in the cleared than in the woodland treatment, due to the negative effect of mesquite on grass production. Variations in broomweed growth characteristics may have implications regarding livestock foraging and wildlife habitat.

\section{Short-Term Mesquite Pod Consumption by Goats Does Not Induce Toxicity \\ Robert W. Cook, Cody B. Scott, and F. Steve Hartmann}

Livestock and wildlife both consume mesquite pods and disperse viable seeds in feces. The one exception appears to be goats, which disperse few viable seeds in feces. The objective of this study was to determine if consumption of mesquite pods by goats would induce toxicity. Goats readily consumed mesquite pods on a short-term basis without suffering toxicosis. If mesquite pods make up more than $90 \%$ of the diet for longer periods ( $>2 \mathrm{wk}$ ), goats may suffer from rumen compaction and toxicosis. 